\title{
Microstructure and Mechanical Properties of SiC Joint Brazed by Al-Ti Alloys as Filler Metal
}

\author{
XU Puhao, ZHANG Xiangzhao, LIU Guiwu, ZHANG Mingfen, GUI Xinyi, QIAO Guanjun \\ (School of Materials Science and Engineering, Jiangsu University, Zhenjiang 212013, China)
}

\begin{abstract}
SiC}$ ceramic has excellent overall properties, and joining it to other materials with high joint strength is an important issue in the actual applications. Brazing of $\mathrm{SiC}$ ceramic to itself was performed using the as-fabricated Al-(10, 20, 30, 40)Ti alloys with nominal Ti concentrations of $10 \%, 20 \%, 30 \%$, and $40 \%$ at $1550{ }^{\circ} \mathrm{C} \times 30 \mathrm{~min}$. The average joint shear strength fluctuates in the range of $\sim 100-260 \mathrm{MPa}$ with the interlayer thickness of $\sim 50 \mu \mathrm{m}$. Moreover, the average strength $\mathrm{SiC} / \mathrm{Al}-20 \mathrm{Ti} / \mathrm{SiC}$ joint is increased markedly with the interlayer thickness decreasing from $\sim 100$ to $25 \mu \mathrm{m}$, reaching the maximum of $\sim 315 \mathrm{MPa}$. Meanwhile, the (Al) phase in the interlayers is reduced gradually till disappear with the thinnest brazing interlayer, leaving the $\mathrm{Al}_{4} \mathrm{C}_{3}, \mathrm{TiC}$ and $(\mathrm{Al}, \mathrm{Si})_{3} \mathrm{Ti}$ phases in the interlayer. The joint fractures of $\mathrm{SiC} / \mathrm{Al}-20 \mathrm{Ti} / \mathrm{SiC}$ joint mainly occur in the $\mathrm{SiC}$ ceramic substrate near the interlayer/ceramic interface.
\end{abstract}

Key words: SiC; brazing; interfaces; microstructures; mechanical property

SiC ceramics are widely applied in many fields including aerospace, electronics, machinery, chemical and metallurgy industries due to the excellent overall properties, such as high strength, high hardness, high melting point, high thermal conductivity, low thermal expansion, as well as good oxidation, corrosion and thermal-shock resistances ${ }^{[1-2]}$. Indeed, joining of $\mathrm{SiC}$ ceramics to other materials is an important issue in these applications due to the inherent difficulties derived from the high degree of covalent bonding in $\mathrm{SiC}$ and the low self-diffusivity ${ }^{[3-4]}$. Presently, joining techniques of $\mathrm{SiC}$ ceramics are mainly involved in brazing, diffusion bonding, transient liquid phase bonding and reaction forming/bonding, etc ${ }^{[1]}$. Among them, the brazing, as the most convenient and highly efficient joining technique, can be divided into active metal brazing ${ }^{[5-7]}$, low activation brazing ${ }^{[8-9]}$ and air reactive brazing $^{[10]}$, etc.

Pure metals can react with $\mathrm{SiC}$ to form silicide+ graphite, $\mathrm{Si}+$ carbide, silicide+carbide, and even ternary compounds ${ }^{[11]}$. Some pure metals (such as $\mathrm{Ti}, \mathrm{Cr}$, and $\mathrm{Zr}$ ) that can produce silicide and carbide simultaneously or ternary compound by reaction with $\mathrm{SiC}$, are commonly deemed as active metals for joining of $\mathrm{SiC}$ ceramics. These active metals were added in pure metals or alloys to form the brazing fill metals, involving binary ${ }^{[5,9,12-15]}$, ternary ${ }^{[6,16-20]}$, quaternary ${ }^{[21-24]}$ and other multi-elemental alloys ${ }^{[7,25]}$. Valenza, et al. ${ }^{[5]}$ performed the pressureless joining of sintered $\mathrm{SiC}$ to itself using Al-25Ti alloy as filler metal by capillary infiltration and using the $\mathrm{Al}_{3} \mathrm{Ti}$ paste/Ti foil/ $/ \mathrm{Al}_{3} \mathrm{Ti}$ paste as interlayer at $1500{ }^{\circ} \mathrm{C}$ for $10 \mathrm{~min}$, and obtained average joint shear strength of 296 and $89 \mathrm{MPa}$ for single lap offset and torsion tests, respectively. Moreover, the additions of these active metals were mainly performed by means of film and coating besides alloying, such as Ti film ${ }^{[26-27]}$ and $\mathrm{Cr}$ coating ${ }^{[20]}$. In addition, in order to reduce the residual thermal stress in joint, some inorganic particulates or nanoplatelets (involving $\mathrm{B}_{4} \mathrm{C}, \mathrm{SiC}, \mathrm{Cr}_{3} \mathrm{C}_{2}$, etc.) with low coefficient of thermal expansion were introduced into $\mathrm{Ag}-\mathrm{Cu}-\mathrm{Ti}$ or $\mathrm{Si}-\mathrm{Ti}$ alloys to form composite fillers for brazing of $\mathrm{SiC}$ ceramics ${ }^{[28-32]}$. Recently, the $\mathrm{Ti}_{3} \mathrm{SiC}_{2}$ MAX phase was also developed as the filler material for joining $\mathrm{SiC}^{[33-34]}$ due to the high strength and thermal stability ${ }^{[35]}$.

As mentioned above, several brazing methods and many brazing filler metals were explored for brazing of $\mathrm{SiC}$ ceramics, and some high-strength $\mathrm{SiC} / \mathrm{SiC}$ joints were obtained too. However, it is quite difficult to optimize the joint strength and high-temperature resistance

Received date: 2021-10-22; Revised date: 2022-01-19; Published online: 2022-01-24

Foundation item: National Natural Science Foundation of China (52002153, 51572112); Natural Science Foundation of the Jiangsu Higher Education Institutions of China (20KJB430004); Key R\&D Plan of Jiangsu Province (BE2019094)

Biography: XU Puhao (1993-), male, PhD candidate. E-mail: 13667004282@163.com 徐谱昊(1993-), 男, 博士研究生. E-mail: 13667004282@163.com

Corresponding author: LIU Guiwu, professor. E-mail: gwliu76@ujs.edu.cn; QIAO Guanjun, professor. E-mail: gjqiao@ujs.edu.cn 刘桂武, 教授.E-mail: gwliu76@ujs.edu.cn; 乔冠军, 教授.E-mail: gjqiao@ujs.edu.cn. 
simultaneously, which lies on the brazing filler or interlayer composition and brazing process to a great extent. For example, Liu, et al. ${ }^{[6]}$ investigated the active metal brazing of sintered $\mathrm{SiC}$ using Ag-35.25Cu-1.75Ti as the brazing filler material at $860-940{ }^{\circ} \mathrm{C}$ for $10-60 \mathrm{~min}$, and obtained the optimal average joint strength of over $340 \mathrm{MPa}$ at room temperature, but these joints can only endure temperature lower than $550{ }^{\circ} \mathrm{C}$. For this purpose, we fabricated four Al-Ti alloys with nominal Ti concentrations of $10 \%-40 \%$ (atom percent) and optimized the alloy composition and thickness based on the variation of room temperature shear strength of $\mathrm{SiC} / \mathrm{SiC}$ brazed joint, and especially investigated the microstructure and phase evolution of joint interlayers for establishing the relationship between joint microstructure and performance. Actually, the four $\mathrm{Al}-\mathrm{Ti} / \mathrm{SiC}$ systems present excellent wettability with contact angle less than $15^{\circ}$, as reported in our previous work $^{[15]}$.

\section{Experimental}

The commercial solid-phase sintered $\mathrm{SiC}$ ceramics with a purity of $98 \%$ and dimensions of $\phi 20 \mathrm{~mm} \times 5 \mathrm{~mm}$ or $\sim 3 \mathrm{~mm} \times 4 \mathrm{~mm} \times 17 \mathrm{~mm}$ (Henan Aryan New Materials Co., Ltd.) were used as substrate for brazing experiments. The pure Al $(\geqslant 99.999 \%)$ and Ti particles $(\geqslant 99.995 \%)$ were used as raw materials for preparation of Al-Ti alloys. In order to remove the oxygen in the cavity of the melting equipment (DHL-300, Shenyang Scientific Instrument Co., LTD., Chinese Academy of Sciences), pure Ti particles of $30 \mathrm{~g}$ were placed in one of crucibles during the first refining, and four kinds of Al-Ti alloys with nominal $\mathrm{Ti}$ concentrations of $10 \%, 20 \%, 30 \%$ and $40 \%$ (atom percent) (Al-(10, 20, 30, 40)Ti) were fabricated by vacuum arc refining for 5 times, respectively. The resulting bulk Al-Ti alloys were processed by wire-electrode cutting and/or grinding into foils with different thicknesses, and then tailored into circular foils of $\phi 20 \mathrm{~mm}$. The microstructures and phase compositions of four Al-Ti alloys were characterized and analyzed by scanning electron microscope (SEM) coupled with energy dispersive spectroscope (EDS) and X-ray diffraction (XRD).

Before brazing, the brazing surfaces of $\mathrm{SiC}$ ceramics and the alloy foils were ground, polished and then ultrasonically cleaned in alcohol. Two $\mathrm{SiC}$ pieces or bars and one alloy foil were assembled together in a graphite mold and then vacuum brazed in a sintering furnace (Highmulti 5000, Japan) at $\sim 7 \mathrm{mPa}$. The pressure $\sim 20 \mathrm{kPa}$ was applied to the top of the $\mathrm{SiC} / \mathrm{Al}-\mathrm{Ti} / \mathrm{SiC}$ couples. For the brazing cycle, the furnace was firstly heated from room temperature to $1200{ }^{\circ} \mathrm{C}$ at $20{ }^{\circ} \mathrm{C} / \mathrm{min}$. Subsequently, the temperature of furnace was further raised to $1500{ }^{\circ} \mathrm{C}$ at $10{ }^{\circ} \mathrm{C} / \mathrm{min}$ and then raised to $1550{ }^{\circ} \mathrm{C}$ at $5{ }^{\circ} \mathrm{C} / \mathrm{min}$ and held for $30 \mathrm{~min}$. Then, the joint sample was cooled down to $300{ }^{\circ} \mathrm{C}$ at rate of $\sim 3{ }^{\circ} \mathrm{C} / \mathrm{min}$ and finally furnace- cooled to room temperature. To evaluate the shear strength of brazed joints, these $\mathrm{SiC} / \mathrm{SiC}$ joints were cut into specimens of $\sim 10 \mathrm{~mm} \times 10 \mathrm{~mm} \times 5 \mathrm{~mm}$, and then the resulting joints were cross-sectioned, polished and observed to investigate the microstructure and phase evolution of joint cross-sections by SEM coupled with EDS. In particular, a thin $\mathrm{Al}-20 \mathrm{Ti} / \mathrm{SiC}$ interface sample was cut from a cross-sectioned $\mathrm{SiC} / \mathrm{Al}-20 \mathrm{Ti} / \mathrm{SiC}$ joint by using focus ion beam (FIB) and observed by transmission electron microscope (TEM). The joint shear strength was evaluated by a shear test method using a DDL100 electronic universal testing machine at the loading speed of $0.5 \mathrm{~mm} / \mathrm{min}$ with clamp and assemble chart shown in Fig. S1. Furthermore, the three-point bending specimens with span of $26 \mathrm{~mm}$ were used to characterize the hightemperature resistance of the typical $\mathrm{SiC} / \mathrm{Al}-20 \mathrm{Ti} / \mathrm{SiC}$ brazed joint on an AG-X plus mechanical testing system under Ar atmosphere. The joined specimens were firstly heated to the testing temperature $\left(800{ }^{\circ} \mathrm{C}\right)$ at a rate of $\sim 33.3{ }^{\circ} \mathrm{C} / \mathrm{min}$ and held for $\sim 7 \mathrm{~min}$, and then the three-point bending test was carried out. The mean value of joint shear strength was obtained from the arithmetical average of 4 samples. The microstructures and phase compositions of joint fracture surfaces were examined and analyzed by SEM coupled with EDS and XRD. The manufacturing, testing and characterization methods of joint shear samples were similarly described in our precious reports $^{[36]}$.

\section{Results and discussion}

\subsection{Brazing alloys}

Fig. 1 shows the BSE images of the nominal Al-(10, 20, 30, 40)Ti alloys, and Fig. 2 shows their XRD patterns. The elemental distributions were also determined by the EDS mapping of the four alloys (Fig. S2). The actual Ti concentrations of the four nominal Al-(10, 20, 30, 40)Ti alloys, determined by EDS, are $12.62 \%, 20.45 \%, 28.61 \%$ and $38.26 \%$ (atom percent), respectively. By combining the XRD patterns, EDS mapping and Al-Ti binary phase $\operatorname{diagram}^{[5]}$, the bright and dark phases are $\mathrm{Al}_{3} \mathrm{Ti}$ and $\mathrm{Al}$ for Al-(10, 20)Ti alloys (Fig. 1(a, b), and Fig. S2), while the bright and gray phases are $\mathrm{Al}_{2} \mathrm{Ti}$ and $\mathrm{Al}_{3} \mathrm{Ti}$ for the Al-30Ti alloy (Fig. 1(c), Fig. 2 and Fig. S2). Moreover, the Al-40Ti alloy is composed of AlTi (bright phases) and Al (gray intergranular phases, determined by the EDS in Fig. S3) although the Al phase is not detected in 

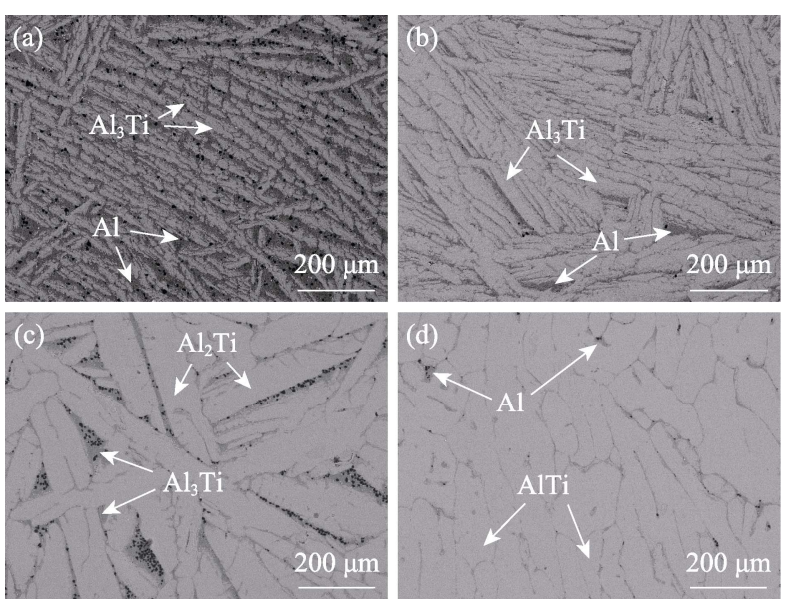

Fig. 1 BSE images of four nominal Al-Ti alloys

(a) Al-10Ti; (b) Al-20Ti; (c) Al-30Ti; (d) Al-40Ti. The black dots are the diamond particles introduced during the polishing

the XRD pattens (Fig. 2) due to amount in Al-40Ti alloy. The main phase composition of Al-Ti alloys gradually transforms from $\mathrm{Al}, \mathrm{Al}_{3} \mathrm{Ti}, \mathrm{Al}_{2} \mathrm{Ti}$ to $\mathrm{AlTi}$ with the $\mathrm{Ti}$ concentration increasing from $10 \%$ to $40 \%$.

\subsection{Joint microstructure evolution}

Fig. 3 shows the cross-sectional BSE images of $\mathrm{SiC} / \mathrm{SiC}$ joints brazed using four nominal Al-(10, 20, 30, 40)Ti alloys with interlayer thickness of $\sim 50 \mu \mathrm{m}$ and the EDS elemental mapping of SiC/Al-20Ti/SiC joint cross-section, and Table 1 lists the EDS results of main phases on the joint cross-sections. As shown in Fig. 3(a, b),

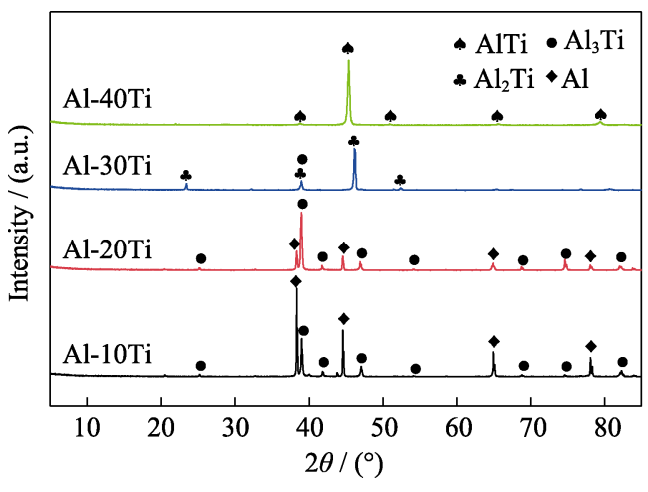

Fig. 2 XRD patterns of Al-Ti alloys

the interlayer of $\mathrm{SiC} / \mathrm{Al}-10 \mathrm{Ti} / \mathrm{SiC}$ joint is composed of (Al), $\mathrm{TiC}$ and $(\mathrm{Al}, \mathrm{Si})_{3} \mathrm{Ti}$ phases, and the $\mathrm{TiC}$ and (Al) phases are mainly distributed at the Al-10Ti/SiC interfaces and in the middle of interlayer, respectively, while the scattered $(\mathrm{Al}, \mathrm{Si})_{3} \mathrm{Ti}$ grains is embedded in the (Al). However, the three phases, (Al), TiC and (Al,Si) $)_{3} \mathrm{Ti}$, are evenly distributed in the interlayer when Al-20Ti alloy is used as brazing filler metal (Fig. 3(c, d)), which contribute to the improvement of joint strength.

The residual (Al) phase in two interlayers of $\mathrm{SiC} / \mathrm{Al}-10 \mathrm{Ti} / \mathrm{SiC}$ and $\mathrm{SiC} / \mathrm{Al}-20 \mathrm{Ti} / \mathrm{SiC}$ joints is mainly attributed to the high concentration of $\mathrm{Al}$ in Al-10Ti and Al-20Ti alloys. Compared with Al-10Ti, the (Al) phase in original Al-20Ti is sharply decreased, leaving discrete (Al) in the interlayer after the serious interfacial
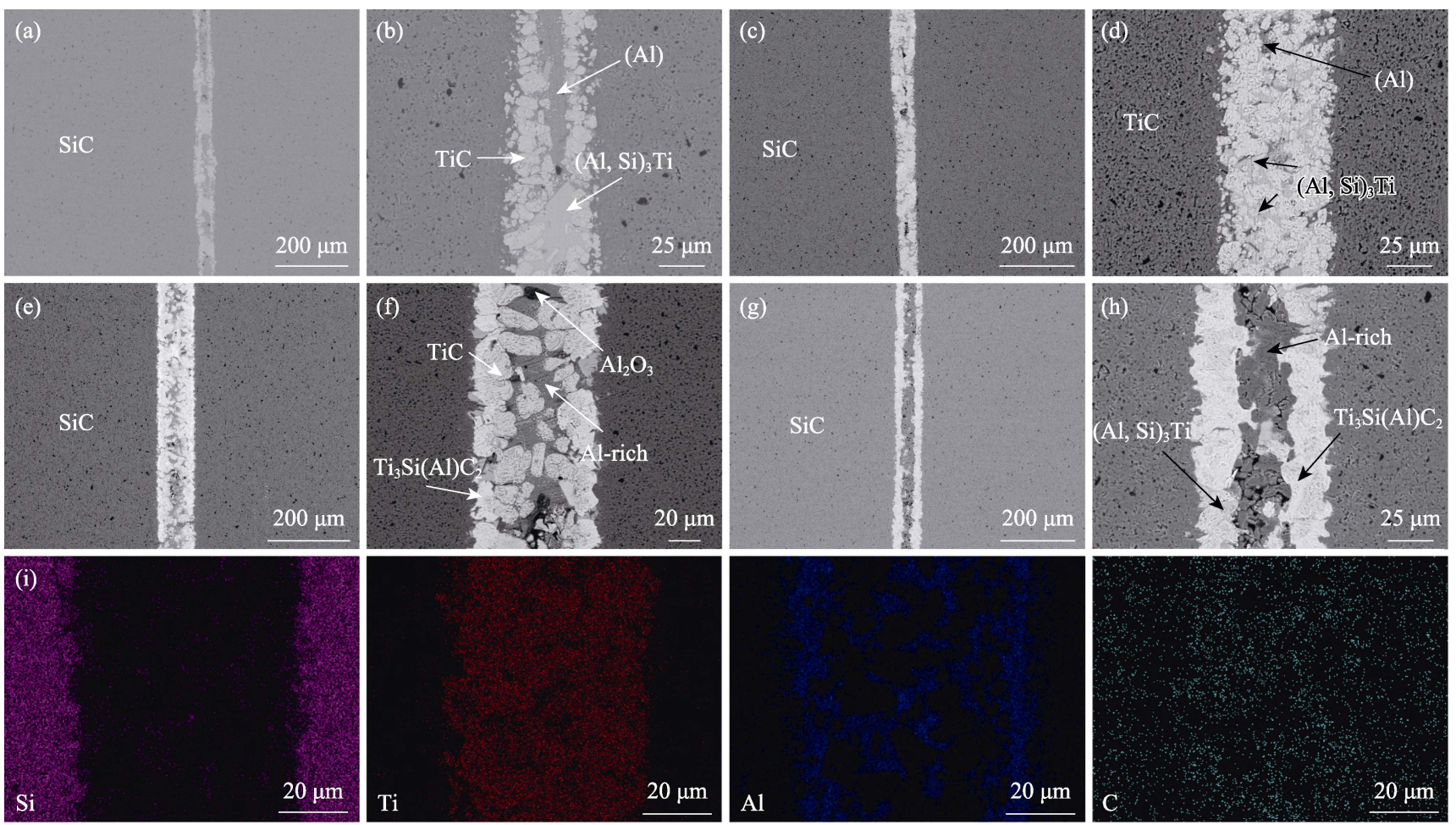

Fig. 3 Cross-sectional BSE images of $\mathrm{SiC} / \mathrm{SiC}$ joints brazed using the four nominal Al-Ti alloys $(\mathrm{a}-\mathrm{h})$ and corresponding EDS elemental mapping (i) (a, b) Al-10Ti; (c, d) Al-20Ti; (e, f) Al-30Ti; (g, h) Al-40Ti 
Table 1 EDS results of partial phases in joint interlayers (atom percent)

\begin{tabular}{|c|c|c|c|c|c|}
\hline \multirow{2}{*}{ Data from } & \multicolumn{4}{|c|}{ Elemental composition $/ \%$} & \multirow{2}{*}{$\begin{array}{c}\text { Possible } \\
\text { phases }\end{array}$} \\
\hline & $\mathrm{Ti}$ & $\mathrm{Al}$ & $\mathrm{C}$ & $\mathrm{Si}$ & \\
\hline \multirow{3}{*}{ Fig. 3(b) } & 0.87 & 98.04 & - & 1.09 & $(\mathrm{Al})$ \\
\hline & 55.33 & - & 45.67 & - & $\mathrm{TiC}$ \\
\hline & 25.85 & 62.83 & - & 11.32 & $(\mathrm{Al}, \mathrm{Si})_{3} \mathrm{Ti}$ \\
\hline \multirow{3}{*}{ Fig. 3(d) } & - & 98.91 & - & 1.09 & $(\mathrm{Al})$ \\
\hline & 53.98 & 0.06 & 45.11 & 0.84 & $\mathrm{TiC}$ \\
\hline & 26.27 & 59.23 & 2.47 & 12.03 & $(\mathrm{Al}, \mathrm{Si})_{3} \mathrm{Ti}$ \\
\hline Fig. 3(f) & 48.61 & 1.85 & 31.39 & 18.15 & $\mathrm{Ti}_{3} \mathrm{Si}(\mathrm{Al}) \mathrm{C}_{2}$ \\
\hline Fig. 3(h) & 50.29 & 1.26 & 30.42 & 18.03 & $\mathrm{Ti}_{3} \mathrm{Si}(\mathrm{Al}) \mathrm{C}_{2}$ \\
\hline
\end{tabular}

interactions (Fig. 3(d)). EDS elemental mapping images further demonstrate the relatively uniform elemental distributions and elemental compositions of main phases in the joint cross-sections (Fig. 3(i)). Surprisely, a dark Al-rich layer involving ( $\mathrm{Al}$ ) solid solution and $\mathrm{Al}_{2} \mathrm{O}_{3}$ phases is located in the middle of interlayers while employing the other two Al-Ti alloys with higher $\mathrm{Ti}$ concentrations (Fig. 3(e-h)), which is obviously different from the cross-sectional microstructures in previous report ${ }^{[5]}$. The formation of Al-rich layer can be derived from the formation of a large amount of $\mathrm{Ti}_{3} \mathrm{SiC}_{2} \mathrm{MAX}$ phase, which consumes a lot of $\mathrm{Ti}, \mathrm{Si}$ and $\mathrm{TiC}^{[37]}$. The elemental and phase distributions were further demonstrated by the typical EDS mapping of $\mathrm{SiC} / \mathrm{Al}-30 \mathrm{Ti} / \mathrm{SiC}$ joint (Fig. S4). As a result, the TiC content increases gradually and then decreases with the Ti concentration increasing from $10 \%$ to $40 \%$.

Fig. 4 shows the cross-sectional BSE images of $\mathrm{SiC} / \mathrm{SiC}$ joints brazed using the nominal Al-20Ti alloys with interlayer thicknesses of $25-100 \mu \mathrm{m}$. As shown in Fig. 4, no Al-rich layer nor $\mathrm{Ti}_{3} \mathrm{Si}(\mathrm{Al}) \mathrm{C}_{2}$ phase can form on the cross-sections of joints, and the $(\mathrm{Al})$ phase decreases
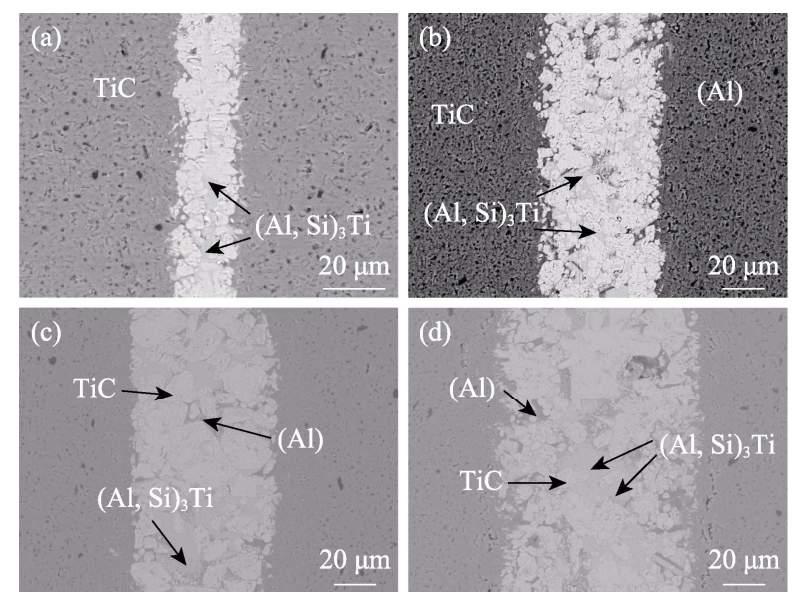

Fig. 4 Cross-sectional BSE images of SiC/Al-20Ti/SiC joints brazed with interlayers of different thickness (a) $\sim 25 \mu \mathrm{m}$; (b) $50 \mu \mathrm{m}$; (c) $70 \mu \mathrm{m}$; (d) $100 \mu \mathrm{m}$ gradually till disappear with the interlayer thickness decreasing from $\sim 100 \mu \mathrm{m}$ to $25 \mu \mathrm{m}$. Undoubtedly, the absence of low melting point of (Al) phase can contribute to the high-temperature resistance of $\mathrm{SiC} / \mathrm{SiC}$ brazed joints. Moreover, some cracks are produced in the ceramic substrate near the interface (Fig. 4(d)), which can bring a negative effect on the joint strength. To clarify the interfacial microstructure and phase composition of the $\mathrm{SiC} / \mathrm{Al}-20 \mathrm{Ti} / \mathrm{SiC}$ joint sample with the thinnest interlayer, a HRTEM analysis was performed on the $\mathrm{Al}-20 \mathrm{Ti} / \mathrm{SiC}$ interface sample prepared by means of FIB. As shown in Fig. 5 and Fig. S5, some bright and dark phases can co-exist at the interlayer/ $\mathrm{SiC}$ interfaces, which can be determined as $\mathrm{TiC}$ and $\mathrm{Al}_{4} \mathrm{C}_{3}$ with interplanar spacings of 0.2164 and $0.1787 \mathrm{~nm}$ according to HRTRM analyses and their SAED patterns, resulting in formation of $\mathrm{TiC} / \mathrm{SiC}$ and $\mathrm{Al}_{4} \mathrm{C}_{3} / \mathrm{TiC}$ interfaces. Meanwhile, some $(\mathrm{Al}, \mathrm{Si})_{3} \mathrm{Ti}$ phases are formed near the $\mathrm{TiC}$ and $\mathrm{Al}_{4} \mathrm{C}_{3}$ phases according to the EDS elemental mapping (Fig. S5). A microcrack is also observed due to the difference of coefficient of thermal expansion (CTE) between the TiC and $(\mathrm{Al}, \mathrm{Si})_{3} \mathrm{Ti}$ phases, which can reduce the joint strength to a certain degree.

\subsection{Joint microstructure evolution}

Fig. 6 shows the variations of joint shear strength with the $\mathrm{Ti}$ concentration of $\mathrm{Al}-\mathrm{Ti}$ alloys and the interlayer thickness of Al-20Ti alloy. The average joint shear strength fluctuates in the range of $\sim 100-260 \mathrm{MPa}$ with the Ti concentration of Al-Ti alloys increasing from 10\% to $40 \%$ (Fig. 6(a)). Considering the interlayer thickness of $\sim 50 \mu \mathrm{m}$, the optimal $\mathrm{SiC} / \mathrm{SiC}$ brazed joint with the maximum average joint strength of $266 \mathrm{MPa}$ is obtained when using the Al-20Ti alloy as brazing filler metal, namely that the highest joint strength is mainly attributed to the lowest thermal stress generated from the uniform phase distribution (Fig. 3(d, i)). Furthermore, the average joint strength is increased markedly with the interlayer thickness decreasing from $\sim 100 \mu \mathrm{m}$ to $25 \mu \mathrm{m}$, arriving at the maximum of $\sim 315 \mathrm{MPa}$, which is comparable to that of the $\mathrm{SiC}$ joint brazed using Al-25Ti alloy as filler material ${ }^{[5]}$. Similarly, this variation of joint strength with interlayer thickness is related to the interlayer microstructure and phase composition. The absence of (Al) phase in the interlayer is contribute to the improvement of joint strength based on the formation of residual thermal stress due to the difference of CTE between the $\mathrm{SiC}$ substrate and interlayer composition materials, where the CTEs of $\mathrm{SiC}, \mathrm{Al}_{3} \mathrm{Ti}, \mathrm{TiC}, \mathrm{Ti}_{3} \mathrm{SiC}_{2}$ and $\mathrm{Al}$ are $4.70 \times 10^{-6} /{ }^{\circ} \mathrm{C},(3.9-4.2) \times 10^{-6} /{ }^{\circ} \mathrm{C}, 7.40 \times 10^{-6} /{ }^{\circ} \mathrm{C}, 8.87 \times 10^{-6} /{ }^{\circ} \mathrm{C}$ and $23.21 \times 10^{-6} /{ }^{\circ} \mathrm{C}$, respectively ${ }^{[5,37]}$. On the other hand, the possibility of emerging cracks during the shear test is reduced sharply with the interlayer thickness decreasing, 

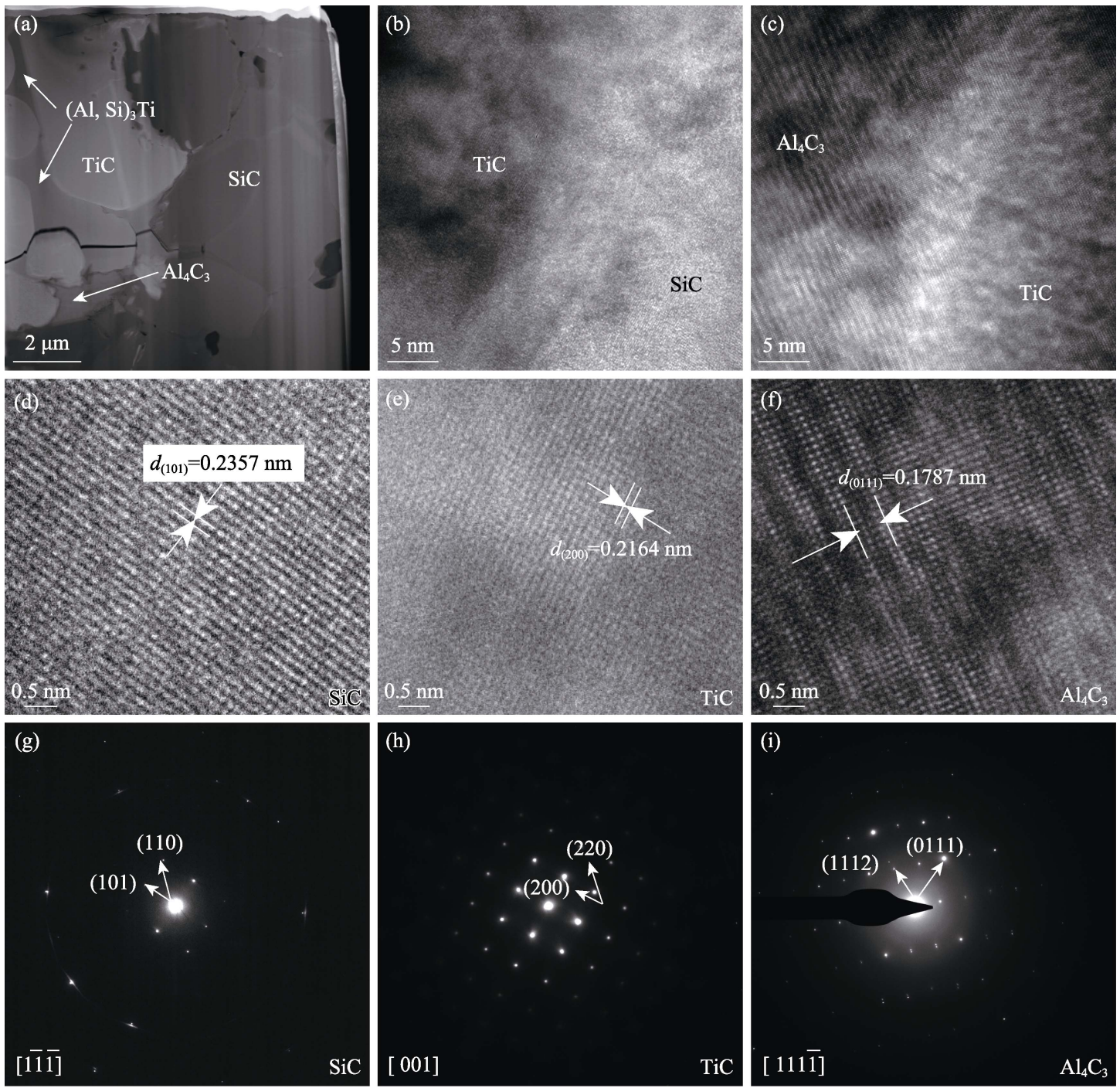

Fig. 5 Interfacial (a) TEM and (b-f) HRTEM images of SiC/Al-20Ti/SiC joint sample with interlayer thickness of $\sim 25 \mu \mathrm{m}$ and the corresponding (g-i) SAED patterns
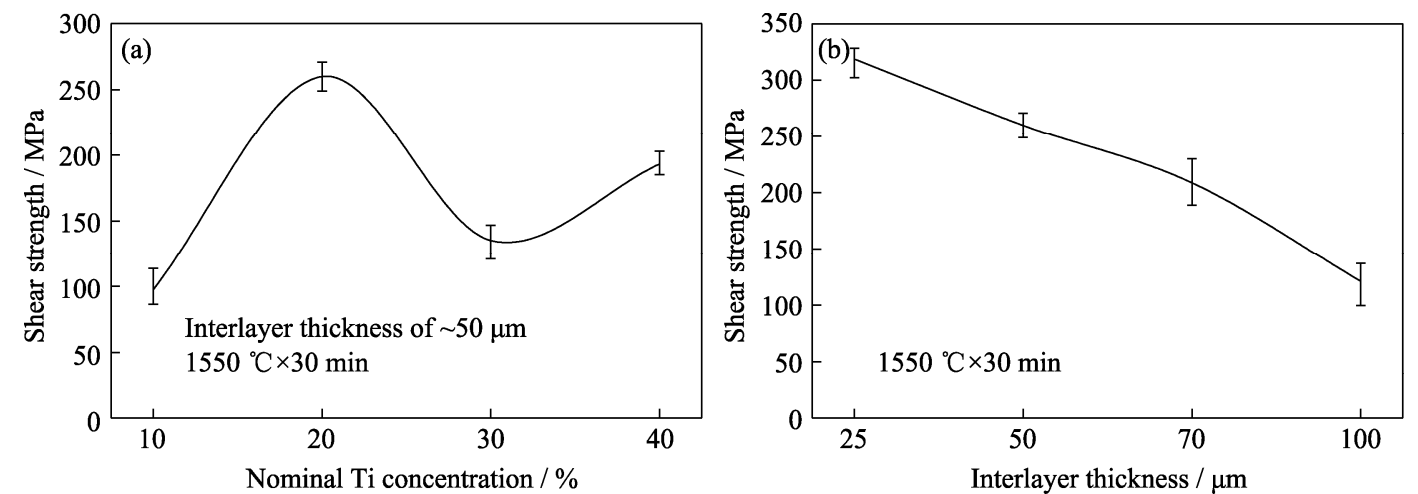

Fig. 6 Variations of joint shear strength with (a) Ti concentration of Al-Ti alloys and (b) interlayer thickness of Al-20Ti alloy

and thus the joint strength trends to increase. Actually, the joint 3-point bending strength of $\mathrm{SiC} / \mathrm{Al}-20 \mathrm{Ti} / \mathrm{SiC}$ brazed joint can reach $\sim 53 \mathrm{MPa}$ at $800{ }^{\circ} \mathrm{C}$, indicating that the brazed joint presents a good high-temperature resistance.

Fig. 7 and Fig. 8 show the typical fracture surface morphologies of $\mathrm{SiC} / \mathrm{SiC}$ joints brazed using four nominal
Al-Ti alloys and the corresponding XRD patterns of fracture surfaces. It is found that the joint fractures mainly occur in the interlayer, in the $\mathrm{SiC}$ ceramic substrate and at the $\mathrm{Al}-\mathrm{Ti} / \mathrm{SiC}$ interface during the shear test. From Fig. 7(a, b), one of the SiC/Al- 10Ti/SiC joint fractures occurs in the $\mathrm{SiC}$ ceramic substrate, with the fracture path passing across the interlayer, leaving the 

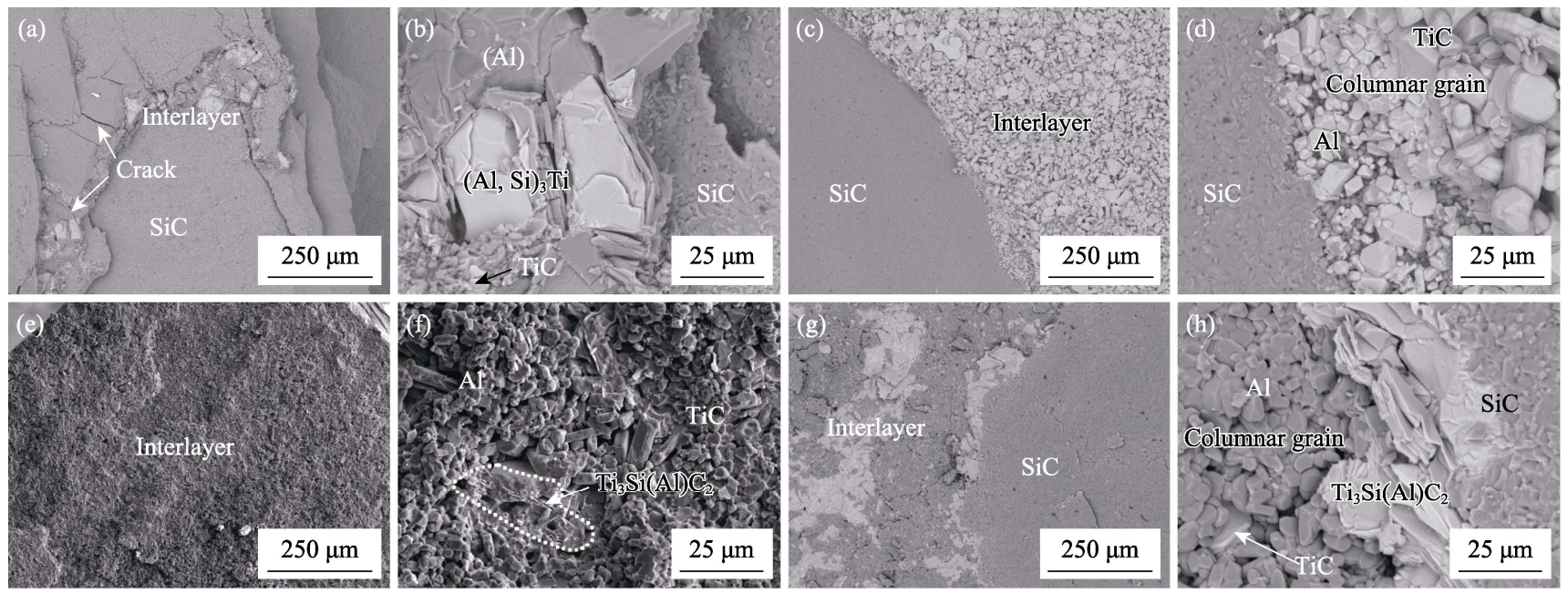

Fig. 7 Typical fracture surface morphologies of $\mathrm{SiC} / \mathrm{SiC}$ joints brazed using different nominal Al-Ti alloys (a, b) Al-10Ti; (c, d) Al-20Ti; (e, f) Al-30Ti ; (g, h) Al-40Ti

(Al), $(\mathrm{Al}, \mathrm{Si})_{3} \mathrm{Ti}$ and $\mathrm{TiC}$ on the fracture surface (Fig. 8). These cracks originated from the difference of CTE among the newly formed phases can reduce the joint strength. Most of the $\mathrm{SiC} / \mathrm{Al}-20 \mathrm{Ti} / \mathrm{SiC}$ joint fractures occur in the $\mathrm{SiC}$ ceramic substrate near the interlayer/ ceramic interface, showing good interfacial bonding. However, only one $\mathrm{SiC} / \mathrm{Al}-20 \mathrm{Ti} / \mathrm{SiC}$ joint with interlayer thickness of $\sim 50 \mu \mathrm{m}$ breaks off at the interface, with the crack going along the interlayer partially (Fig. 7(c)), leaving only $\mathrm{TiC}$ on the fracture surface (Fig. 8). Moreover, all the $\mathrm{SiC} / \mathrm{Al}-(30,40) \mathrm{Ti} / \mathrm{SiC}$ joint fractures take place in the interlayer (Fig. 7(e)) or at the $\mathrm{Al}-\mathrm{Ti} / \mathrm{SiC}$ interface. Moreover, the cracks in the interlayer are reduced sharply with the Ti content increasing, thus showing an increasing trend of joint strength. For instance, one of the SiC/Al40Ti/SiC joint fractures initiates in the interlayer and ends at the $\mathrm{Al}-\mathrm{Ti} / \mathrm{SiC}$ interface, exposing the laminated $\mathrm{Ti}_{3} \mathrm{Si}(\mathrm{Al}) \mathrm{C}_{2}$, columnar $\mathrm{TiC}$ and near-equiaxial $\mathrm{Al}$ grains (Fig. 7(g, h) and Fig. 8). The TiC and Al phases with special morphologies are mainly attributed to the crystal nucleation and growth during the whole brazing process and cooling, respectively.

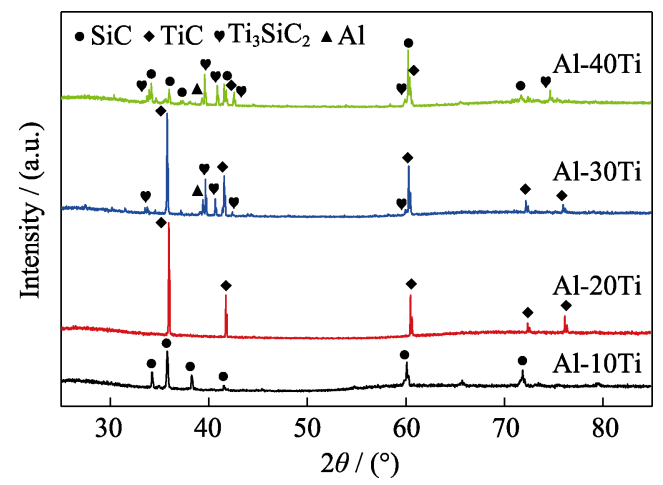

Fig. 8 XRD patterns of fracture surfaces of $\mathrm{SiC} / \mathrm{SiC}$ joints brazed using various nominal Al-Ti alloys

\section{Conclusions}

Brazing of $\mathrm{SiC}$ ceramic to itself was performed using as-prepared $\mathrm{Al}-\mathrm{Ti}$ alloys as filler metals and the microstructure, phase evolution and shear strength of the brazed joint were discussed. Considering the interlayer thickness of $\sim 50 \mu \mathrm{m}$, the uniform phase distribution is only observed in the $\mathrm{SiC} / \mathrm{Al}-20 \mathrm{Ti} / \mathrm{SiC}$ joint, and the $\mathrm{Ti}_{3} \mathrm{Si}(\mathrm{Al}) \mathrm{C}_{2}$ MAX phase can form at the $\mathrm{Al}-(30,40) \mathrm{Ti} /$ $\mathrm{SiC}$ interfaces. The $(\mathrm{Al})$ phase in the interlayer decreases gradually till disappear with the interlayer thickness decreasing from $\sim 100 \mu \mathrm{m}$ to $25 \mu \mathrm{m}$ when the Al-20Ti alloys is used as filler metal. The average joint shear strength fluctuates in the range of 100-260 MPa with the interlayer of $\sim 50 \mu \mathrm{m}$. The average strength $\mathrm{SiC} / \mathrm{Al}-20 \mathrm{Ti} /$ $\mathrm{SiC}$ joint is increased markedly with the interlayer thickness decreasing from $\sim 100 \mu \mathrm{m}$ to $25 \mu \mathrm{m}$, reaching the maximum of $\sim 315 \mathrm{MPa}$. Most of $\mathrm{SiC} / \mathrm{Al}-20 \mathrm{Ti} / \mathrm{SiC}$ joint fractures occur in the ceramic substrate near the interlayer/ceramic interface, while those of $\mathrm{SiC} / \mathrm{Al}-(10$, $30,40) \mathrm{Ti} / \mathrm{SiC}$ joints appear in the interlayer, at the interface and in the $\mathrm{SiC}$ ceramic substrate with the crack crossing the interlayer.

\section{Supporting Materials}

Supporting materials related to this article can be found at https://doi.org/10.15541/jim20210652.

\section{References:}

[1] LIU G W, ZHANG X Z, YANG J, et al. Recent advances in joining of $\mathrm{SiC}$-based materials (monolithic $\mathrm{SiC}$ and $\mathrm{SiC}_{\mathrm{f}} / \mathrm{SiC}$ composites): joining processes, joint strength, and interfacial behavior. Journal of Advanced Ceramics, 2019, 8(1): 19-38.

[2] ZHAO S, YANG Z C, ZHOU X G. Fracture behavior of SiC/SiC 
composites with different interfaces. Journal of Inorganic Materials, 2016, 31(1): 58-62.

[3] FERNIE J, DREW R, KNOWLES K. Joining of engineering ceramics. International Materials Reviews, 2009, 54: 283-331.

[4] YOON D H, REIMANIS I E. A review on the joining of $\mathrm{SiC}$ for high-temperature applications. Journal of the Korean Ceramic Society, 2020, 57(5): 246-270.

[5] VALENZA F, GAMBARO S, MUOLO M L, et al. Wetting of SiC by Al-Ti alloys and joining by in-situ formation of interfacial $\mathrm{Ti}_{3} \mathrm{Si}(\mathrm{Al}) \mathrm{C}_{2}$. Journal of the European Ceramic Society, 2018, 38(11): 3727-3734.

[6] LIU Y, HUANG Z R, LIU X J. Joining of sintered silicon carbide using ternary $\mathrm{Ag}-\mathrm{Cu}-\mathrm{Ti}$ active brazing alloy. Ceramics International, 2009, 35(8): 3479-3484.

[7] XIONG H P, WEI M, XIE Y H, et al. Control of interfacial reactions and strength of the $\mathrm{SiC} / \mathrm{SiC}$ joints brazed with newlydeveloped Co-based brazing alloy. Journal of Materials Research, 2007, 22(10): 2727-2736.

[8] KOLTSOV A, HODAJ F, EUSTATHOPOULOS N. Brazing of AlN to $\mathrm{SiC}$ by $\mathrm{Pr}$ silicides: physicochemichal aspects. Materials Science and Engineering: A, 2008, 495(1/2): 259-264.

[9] RICCARDI B, NANNETTI C A, WOLTERSDORF J, et al. Joining of $\mathrm{SiC}$ based ceramics and composites with $\mathrm{Si}-16 \mathrm{Ti}$ and Si-18Cr eutectic alloys. International Journal of Materials \& Product Technology, 2004, 20(5): 440-451.

[10] ZHAO S T, ZHAGN X Z, LIU G W, et al. Surface metallization of $\mathrm{SiC}$ ceramic by Mo-Ni-Si coatings for improving its wettability by molten Ag. Rare Metal Materials and Engineering, 2018, 47(3): 759-765.

[11] LIU G W, MUOLO M L, VALENZA F, et al. Survey on wetting of $\mathrm{SiC}$ by molten metals. Ceramics International, 2010, 36(4): $1177-1188$.

[12] ZHAO H T, HUANG J H, ZHANG H, et al. Vacuum brazing of $\mathrm{Si} / \mathrm{SiC}$ ceramic and low expansion titanium alloy by using $\mathrm{Cu}-\mathrm{Ti}$ fillers. Rare Metal Materials and Engineering, 2007, 36(12): 2184-2188.

[13] LI J K, LIU L, LIU X. Joining of SiC ceramic by 22Ti-78Si hightemperature rutectic brazing alloy. Journal of Inorganic Materials, 2011, 26(12): 1314-1318.

[14] FU W, SONG X G, TIAN R C, et al. Wettability and joining of SiC by Sn-Ti: Microstructure and mechanical properties. Journal of Materials Science and Technology, 2020, 40: 15-23.

[15] XU P H, GUI X Y, ZHANG X Z, et al. Wetting and interfacial behavior of Al-Ti/4H-SiC system: a combined study of experiment and DFT simulation. Ceramics International, 2021, 47: 69-77.

[16] HAO Z T, WANG D P, YANG Z W, et al. Microstructural evolution and mechanical properties of $\mathrm{FeNi}_{42}$ alloy and $\mathrm{SiC}$ ceramic joint vacuum brazed with Ag-based filler metals. Ceramics International, 2020, 46(8): 12795-12805.

[17] PRAKASH P, MOHANDAS T, RAJU P D. Microstructural characterization of $\mathrm{SiC}$ ceramic and SiC-metal active metal brazed joints. Scripta Materialia, 2005, 52(11): 1169-1173.

[18] TIAN W B, SUN Z M, ZHANG P, et al. Brazing of silicon carbide ceramics with Ni-Si-Ti powder mixtures. Journal of the Australian Ceramic Society, 2017, 53(2): 511-516.

[19] SUDMEYER I, HETTESHEIMER T, ROHDE M. On the shear strength of laser brazed SiC-steel joints: effects of braze metal fillers and surface patterning. Ceramics International, 2010, 36(3): 1083-1090.

[20] CHEN Z B, HU S P, SONG X G, et al. Brazing of SiC ceramics pretreated by chromium coating using inactive $\mathrm{AgCu}$ filler metal. International Journal of Applied Ceramic Technology, 2020, 17(6):
2591-2597.

[21] LIU Y, ZHU Y Z, YANG Y, et al. Microstructure of reaction layer and its effect on the joining strength of $\mathrm{SiC} / \mathrm{SiC}$ joints brazed using Ag-Cu-In-Ti alloy. Journal of Advanced Ceramics, 2014, 3(1): $71-75$.

[22] MOSZNER F, MATA-OSORO G, CHIODI M, et al. Mechanical behavior of $\mathrm{SiC}$ joints brazed using an active $\mathrm{Ag}$-Cu-In-Ti braze at elevated temperatures. International Journal of Applied Ceramic Technology, 2017, 14(4): 703-711.

[23] HE H M, LU C Y, HE H M, et al. Characterization of SiC ceramic joints brazed using Au-Ni-Pd-Ti high-temperature filler alloy. Materials, 2019, 12(6): 931.

[24] QIN Q, ZHANG J, LU CJ, et al. Microstructure and mechanical properties of the $\mathrm{SiC} / \mathrm{Zr}_{4}$ joints brazed with $\mathrm{TiZrNiCu}$ filler for nuclear application. Progress in Natural Science-Materials International, 2018, 28(3): 124-131.

[25] XIONG H P, WEI M, XIE Y H, et al. Brazing of SiC to a wrought nickel-based superalloy using $\mathrm{CoFeNi}(\mathrm{Si}, \mathrm{B}) \mathrm{CrTi}$ filler metal. Materials Letters, 2007, 61(25): 4662-4665.

[26] SONG X G, CHEN Z B, HU S P, et al. Wetting behavior and brazing of titanium-coated $\mathrm{SiC}$ ceramics using $\mathrm{Sn}_{0.3} \mathrm{Ag}_{0.7} \mathrm{Cu}$ filler. Journal of the American Ceramic Society, 2019, 103(2): 912-920.

[27] CHEN Z B, BIAN H, NIU C N, et al. Titanium-deposition assisted brazing of $\mathrm{SiC}$ ceramics using inactive $\mathrm{AgCu}$ filler. Materials Characterization, 2018, 142: 219-222.

[28] DAI X Y, CAO J, CHEN Z, et al. Brazing SiC ceramic using novel $\mathrm{B} 4 \mathrm{C}$ reinforced $\mathrm{Ag}-\mathrm{Cu}-\mathrm{Ti}$ composite filler. Ceramics International, 2016, 42(5): 6319-6328.

[29] LIU Y, QI Q, ZHU Y, et al. Microstructure and joining strength evaluation of $\mathrm{SiC} / \mathrm{SiC}$ joints brazed with $\mathrm{SiC}_{\mathrm{p}} / \mathrm{Ag}-\mathrm{Cu}-\mathrm{Ti}$ hybrid tapes. Journal of Adhesion Science and Technology, 2015, 29(15): $1563-1571$.

[30] LI Z, WEI R W, WEN Q, et al. Microstructure and mechanical properties of $\mathrm{SiC}$ ceramic joints vacuum brazed with in-situ formed $\mathrm{SiC}$ particulate reinforced Si-24Ti alloy. Vacuum, 2019, 173: 109160.

[31] ZHONG Z H, HOU G X, ZHU Z X, et al. Microstructure and mechanical strength of $\mathrm{SiC}$ joints brazed with $\mathrm{Cr}_{3} \mathrm{C}_{2}$ particulate reinforced Ag-Cu-Ti brazing alloy. Ceramics International, 2018, 44(10): $11862-11868$.

[32] SONG Y Y, LIU D, HU S P, et al. Graphene nanoplatelets reinforced $\mathrm{AgCuTi}$ composite filler for brazing $\mathrm{SiC}$ ceramic. Journal of the European Ceramic Society, 2019, 39(4): 696-704.

[33] ZHOU X B, LI Y B, LI Y F, et al. Residual thermal stress of $\mathrm{SiC} / \mathrm{Ti}_{3} \mathrm{SiC}_{2} / \mathrm{SiC}$ joints calculation and relaxed by post-annealing. International Journal of Applied Ceramic Technology, 2018, 15: $1157-1165$.

[34] ZHOU X B, HAN Y H, SHEN X F, et al. Fast joining SiC ceramics with $\mathrm{Ti}_{3} \mathrm{SiC}_{2}$ tape film by electric field-assisted sintering technology. Journal of Nuclear Materials, 2015, 466: 322-327.

[35] YANG D X, ZHOU Y, YAN X H, et al. Highly conductive wear resistant $\mathrm{Cu} / \mathrm{Ti}_{3} \mathrm{SiC}_{2}(\mathrm{TiC} / \mathrm{SiC})$ co-continuous composites via vacuum infiltration process. Journal of Advanced Ceramics, 2020, 9(1): 83-93.

[36] ZHANG X Z, LIU G W, TAO J N, et al. Brazing of WC-8Co cemented carbide to steel using $\mathrm{Cu}-\mathrm{Ni}-\mathrm{Al}$ alloys as filler metal: microstructures and joint mechanical behavior. Journal of Materials Science and Technology, 2018, 34(7): 1180-1188.

[37] ZHOU X B, JING L, KWON Y D, et al. Fabrication of $\mathrm{SiC}_{\mathrm{w}} / \mathrm{Ti}_{3} \mathrm{SiC}_{2}$ composites with improved thermal conductivity and mechanical properties using spark plasma sintering. Journal of Advanced Ceramics, 2020, 9(4): 462-470. 


\title{
$\mathrm{Al}-\mathrm{Ti}$ 合金钎焊 $\mathrm{SiC}$ 陶瓷接头界面微观结构与力学性能
}

\author{
徐谱吴, 张相召, 刘桂武, 张明芬, 桂新易, 乔冠军 \\ (江苏大学 材料科学与工程学院, 镇江 212013)
}

摘 要: $\mathrm{SiC}$ 陶瓷具有优异的综合性能, 通过钎焊获得高强度接头是其获得广泛应用的重要前提。研究采用 $\mathrm{Al}-(10,20$, $30,40) \mathrm{Ti}\left(\mathrm{Ti}\right.$ 的名义原子含量 $10 \% 、 20 \% 、 30 \% 、 40 \%$ ) 系列合金, 在 $1550{ }^{\circ} \mathrm{C}$ 条件下, 对 $\mathrm{SiC}$ 陶瓷进行钎焊 $30 \mathrm{~min}$ 。 当中间层厚度为 $\sim 50 \mu \mathrm{m}$ 时, $\mathrm{SiC}$ 钎焊接头的平均剪切强度处于 100 $260 \mathrm{MPa}$ 范围内。当采用 $\mathrm{Al}-20 \mathrm{Ti}$ 合金作为钎料 时, 随着中间层厚度从 100 $\mu \mathrm{m}$ 减小至 $25 \mu \mathrm{m}$, 钎焊接头的平均强度逐渐提高, 且最大强度 $315 \mathrm{MPa}$ 。同时, 钎焊 中间层中 $(\mathrm{Al})$ 相逐渐减少直至消失, 只留下 $\mathrm{Al}_{4} \mathrm{C}_{3} 、 \mathrm{TiC}$ 和 $(\mathrm{Al}, \mathrm{Si})_{3} \mathrm{Ti}$ 相。 $\mathrm{SiC} / \mathrm{Al}-20 \mathrm{Ti} / \mathrm{SiC}$ 钎焊接头的断裂主要发生 在靠近中间层/陶瓷界面位置的陶瓷基体内。

关 键 词: $\mathrm{SiC}$; 钎焊; 界面; 微结构; 力学性能

中图分类号: TG456 文献标志码: A 


\section{Supporting materials:}

\section{Microstructure and Mechanical Properties of SiC Joint Brazed by Al-Ti Alloys as Filler Metal}

XU Puhao, ZHANG Xiangzhao, LIU Guiwu, ZHANG Mingfen, GUI Xinyi, QIAO Guanjun (School of Materials Science and Engineering, Jiangsu University, Zhenjiang 212013, China)

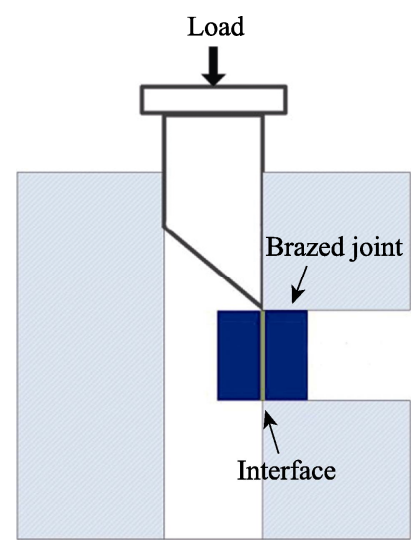

Fig. S1 Schematic of the shear test fixture
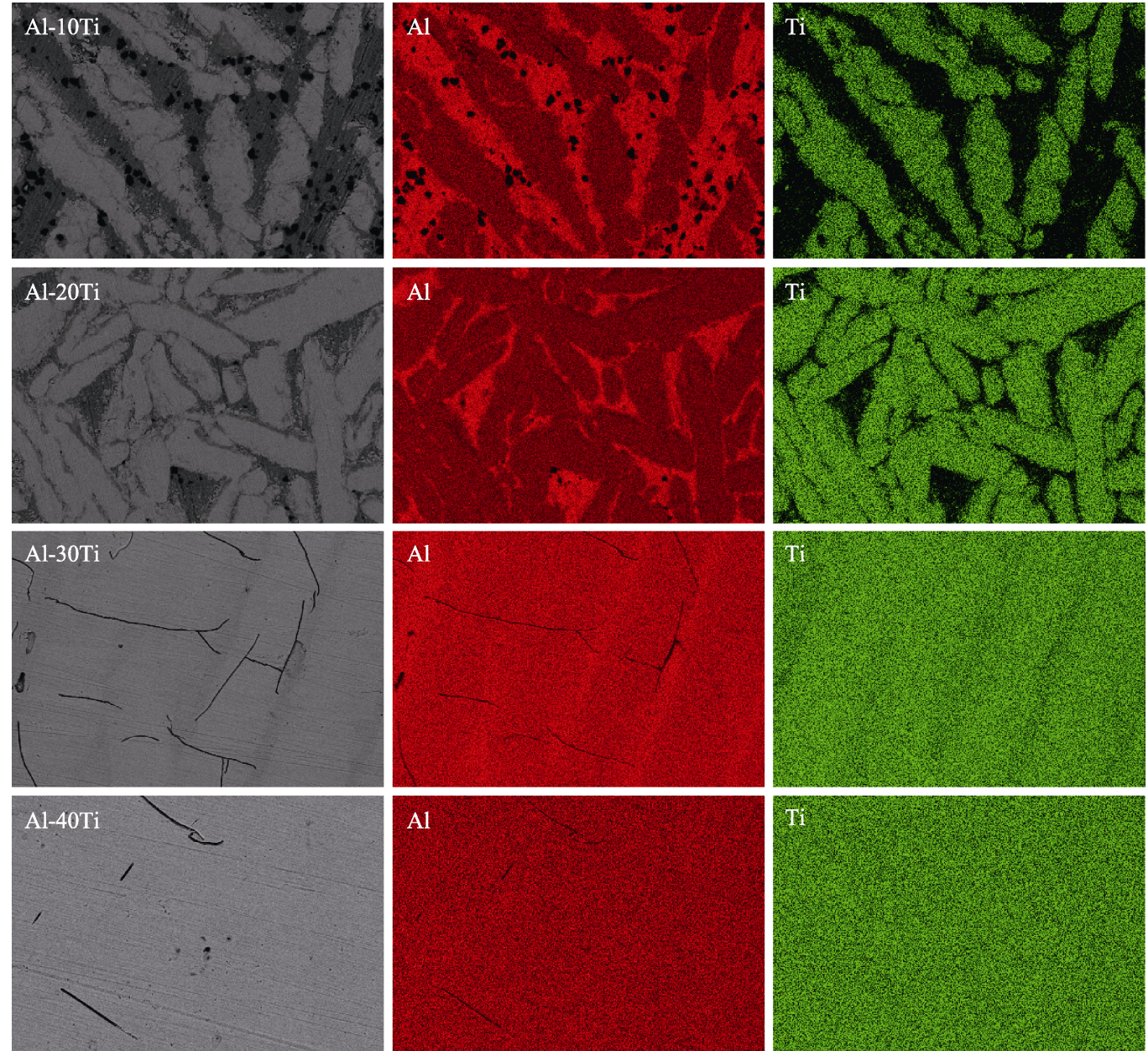

Fig. S2 Typical BSE images of Al-(10, 20, 30, 40)Ti alloys and the corresponding elemental mapping 


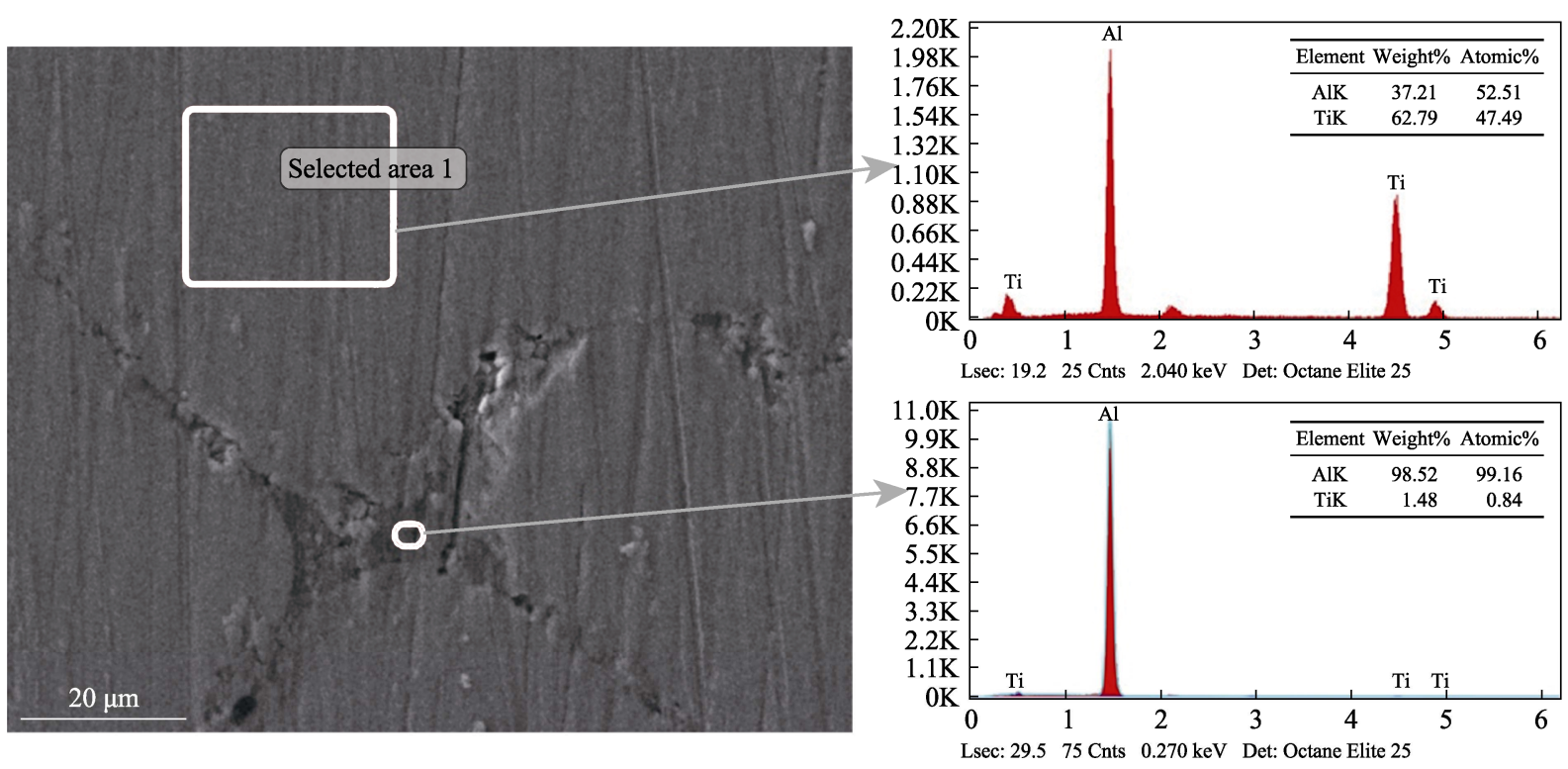

Fig. S3 Typical BSE image of Al-40Ti alloy and the corresponding elemental compositions of the selected area
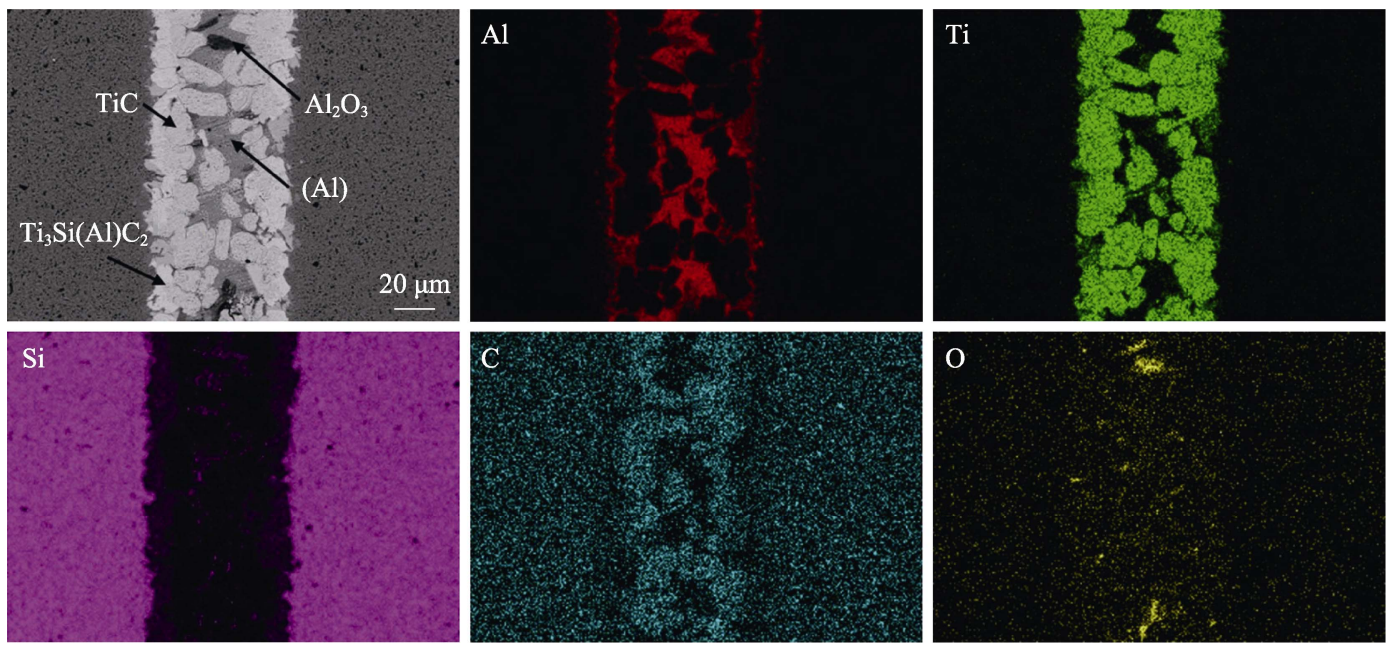

Fig. S4 Cross-sectional BSE image of the $\mathrm{SiC} / \mathrm{Al}-30 \mathrm{Ti} / \mathrm{SiC}$ joint brazed at $1550{ }^{\circ} \mathrm{C} \times 30 \mathrm{~min}$ and the corresponding elemental mappings
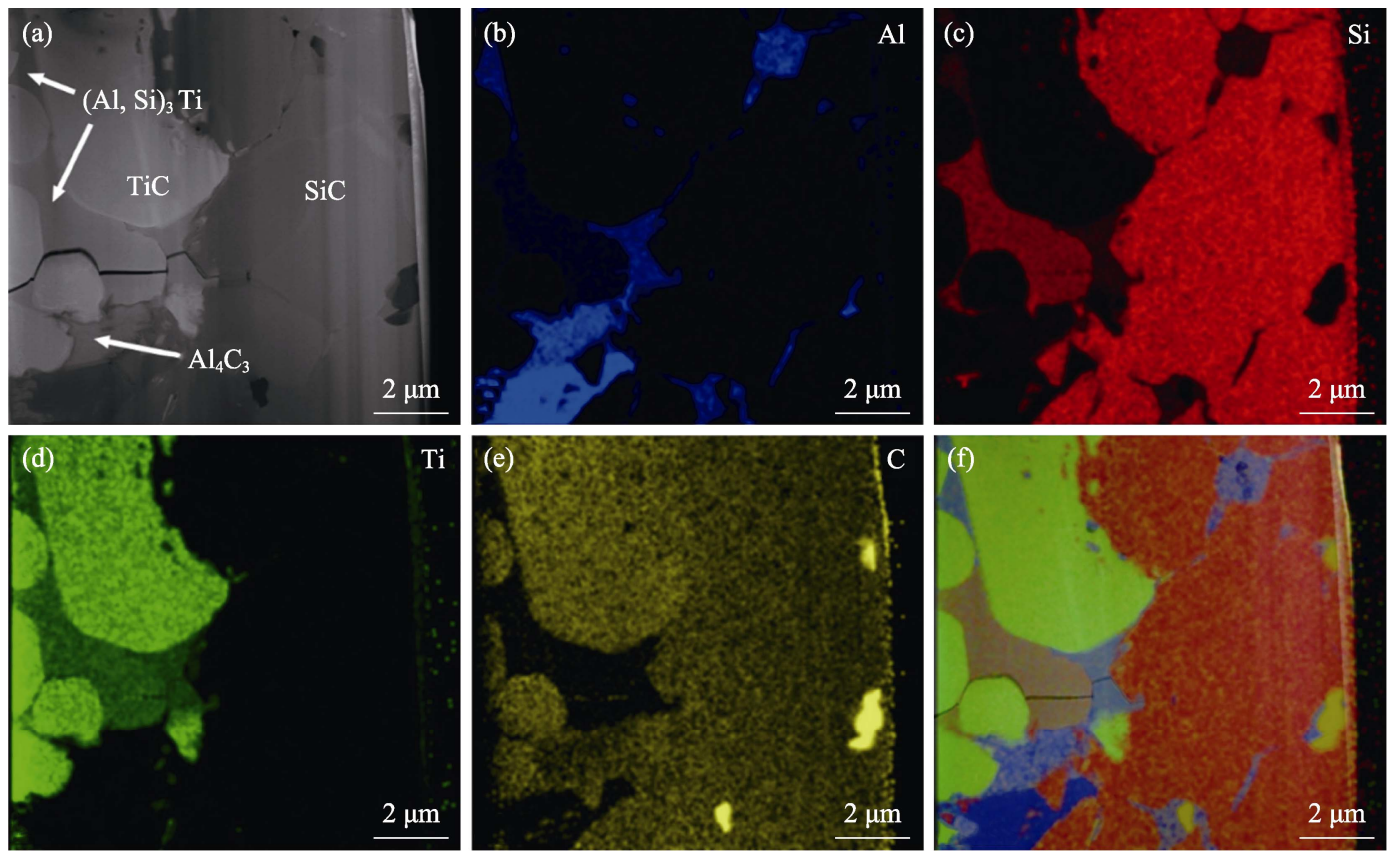

Fig. S5 Interfacial TEM image of $\mathrm{SiC} / \mathrm{Al}-20 \mathrm{Ti} / \mathrm{SiC}$ joint sample and the corresponding elemental mappings 